\title{
Food Habits of Mountain Goats, Mule Deer, and Cattle on Chopaka Mountain, Washing- ton, $1977-1980$
}

\author{
ERICK G. CAMPBELL AND ROLF L. JOHNSON
}

\section{Abstract}

The seasonal food habits of mountain goats, mule deer, and cattle on Chopaka Mountain, Wash.,(1977-1980) were determined by fecal analysis. Graminoids represented $84 \%$ of the fall diet of cattle, the only period when cattle occurred within the mountain goat range. Mountain goats utilized graminoids (42\%) and shrubs (31\%) primarily; whereas, mule deer consumed shrubs (45\%) and conifers (29\%). Dietary overlap was greatest between $\mathrm{mt}$. goats and mule deer $(37 \%)$ and $m t$. goats and cattle (32\%), and minimal between mule deer and cattle (15\%). Considerable intra- and interseasonal variation was experienced for all 3 species.

Local concern has been generated over the drastic decline of mountain (mt.) goats (Oreamnos americanus) on Chopaka Mountain, Wash., since the late 1940's. Advancing plant succession and competition with mule deer (Odocoileus hemionus) and cattle (Bos taurus) for available forage and space were thought to be the prime factors resulting in this reduction. Multiple use mandates upon the Bureau of Land Management made the determination of the interactive food habits of $\mathrm{mt}$. goats, mule deer, and cattle imperative. Forage allocation without such data would be impossible. The purpose of this study was to determine the sea sonal food habits and dietary overlaps for $\mathrm{mt}$. goats, mule deer, and cattle on Chopaka Mountain, Wash.

Historically, food habits studies have usually dealt with a single species of animal. Only recently has the fecal analysis food habits study methodology enabled investigators to quantify and compare herbivore diets (Storr 1961, Sparks and Malechek 1968, Hansen et al. 1973, Todd and Hansen 1973, Dearden et al. 1975).

A number of comparative food habits studies are available for mule deer and cattle (Schwann 1945, Julander 1955, Mackie 1970 McKean and Bartmann 1971, Constan 1973, Hansen and Reid 1975, Hubbard and Hansen 1976, Hansen et al. 1977, Hansen and Clark 1977), but no comparative studies are available for mt. goats. Previous comparative food habits studies have demonstrated that ungulate food habits studies and their relationships vary considerably depending upon the specific ungulate involved, sampling techniques, location of study, year of study, and season of study. Generalization of food habits and their relationships are, therefore, rarely reliable.

Mt. goat food habits studies (Anderson 1940, Harmon 1944, Casebeer 1948, Brandborg 1955, Saunders 1955, Hibb 1967, Kuck 1970) have been limited in scope and sample size due to the relatively inaccessible habitat of the animals.

Authors are wildlife biologist, U.S. Bureau of Land Management, Safford, Ariz., and wild life biologist, Washington Department of Game, Olympia, Wash.

This study was supported by the U.S. Bureau of Land Management, Pittman Robertson Project 88R, and the Washington Department of Game. We appreciate the assistance of Bruce Davitt of the Wildlife Habitat Laboratory at Washington State University for microhistological fecal analysis and Jerry King and Bill Hebner of the Washington Department of Game for fecal sample collection. We also wish to acknowledge the critical review of the manuscript by Raul Valdez, David Kitchen, and R.M. Hansen.

Manuscript received September 14, 1981.

\section{Study Area}

The study area, Chopaka Mountain, is located in northcentral Washington approximately $24 \mathrm{~km}$ west of Oroville. Mt. goats utilized approximately 2,400 ha of the mountain at elevations ranging from $2,388 \mathrm{~m}$ on Chopaka Mountain down to $360 \mathrm{~m}$ in the Similkameen Valley. Annual precipitation varied from $65 \mathrm{~cm}$ at the higher elevations to $38 \mathrm{~cm}$ in the valley. Snowpack averaged 2-3 $\mathrm{m}$ on Chopaka Mountain to $0.5 \mathrm{~m}$ in the Similkameen Valley. Seventy-one percent of the area is administered by the Bureau of Land Management, 25\% is administered by the Washington State Department of Natural Resources, and $4 \%$ is privately owned.

Geologically, Chopaka Mountain is an extension of the Cascade Mountain Range, although it borders the Okanogan Highlands and shares similar rock formations. The principal mt. goat range is on the eastern face of Chopaka Mountain where steep cliffs are interlaced with sharp, steep draws and hogback ridges. Cattle utilize the relatively flat terrain on the top and bottom of Chopaka Mountain. Mule deer utilize the entire area, except for the steepest cliffs.

Substantial elevational changes, discontinuous wildfires, and geological outcrops have resulted in a diversity of climax and successional plant communities. The lower elevations are dominated by an open forest composed of ponderosa pine (Pinus ponderosa), Douglas fir (Pseudotsuga menziesii), and bunchgrass (Agropyron spp.) communities. Mixed subalpine fir (Abies lasiocarpa), lodgepole pine (Pinus contorta), and whitebark pine (Pinus albicaulis) communities dominate the higher elevations.

Bunchgrass communities dominate the developed soil sites; whereas, shrubs predominate near rock slides on the poorer soil sites. Bluebunch wheatgrass (Agropyron spicatum), ldaho fescue (Festuca idahoensis), pinegrass (Calamagrostis rubescens), Sandberg's bluegrass (Poa sandbergii), and cheatgrass (Bromus tectorum) are the predominant grasses. Dominant shrubs include buffaloberry (Shepherdia canadensis), currant (Ribes spp.), sagebrush (Artemisia spp.), serviceberry (Amelanchier alnifolia), Oregon grape (Berberis nersosa), ninebark (Physocarpus malvaceous), and snowbrush ceanothus (Ceanothus velutinus).

\section{Methods}

The botanical composition of seasonal diets was determined by microhistological analysis of fecal material. The Wildlife Habitat Laboratory at Washington State University performed all microscopic analysis utilizing standard techniques (Storr 1961, Sparks and Malechek 1968, Williams 1969, Ward 1970).

One composite sample, of at least 10 aliquots, of fecal material was collected each season. Anthony and Smith (1974) in their work on seasonal deer diets in Arizona reported that 15 composited subsamples were sufficient to adequately describe seasonal forage habits. The inaccessibility of mt. goat habitat limited the subsample size of this study to a minimum of ten. All fecal samples were collected from areas in the Anderson Creek drainage where mt. goats, mule deer, and cattle were seen during the winter, spring, summer, or fall periods. Mt. goat and mule deer fecal samples were 
collected at elevations of $450 \mathrm{~m}$ to $1,200 \mathrm{~m}$ during the winter and spring periods, while summer and fall collections were from 1,800 $\mathrm{m}$ to $2,300 \mathrm{~m}$. Cattle fall samples were collected at $2,300 \mathrm{~m}$ elevation.

Kulcyznski's similarity index (Oosting 1956) was used to compare forage overlap.

\section{Results}

Tables 1, 2, and 3 detail the seasonal food habits of mt. goats, mule deer, and cattle, respectively. Considerable intra- and interseasonal variation occurred between seasons and species of ungulate.

Fifty-four plant species were identified in the fecal samples from mt. goats. Graminoids accounted for almost one-half of the mt. goat diet, with the exception of the winter period. Shrubs and conifers were of secondary and tertiary importance, respectively. Conifer use was greatest during the winter period when other forage items were not as readily accessible. Dietary overlap was greater between mt. goats and mule deer $(37 \%)$ than $\mathrm{mt}$. goats and cattle $(32 \%)$.

Forty-seven plant species were identified in the fecal samples from mule deer. Shrubs and conifers constituted the primary and secondary forage items of mule deer, respectively. Graminoids and forbs combined never accounted for more than approximately one-third of the diet. Dietary overlap between mule deer and mt. goats $(37 \%)$ was double that of mule deer and cattle $(15 \%)$.

Twenty-eight plant species were identified in the fall fecal samples from cattle. Cattle predominantly utilized graminoids $(84 \%)$, with Carex spp. accounting for $53 \%$ of their fall diet. Dietary overlap between cattle and mule deer was half (15\%) that of cattle and $\mathrm{mt}$. goats (32\%).

\section{Discussion}

Knowledge of the food habits of an ungulate, or any organism for that matter, is of paramount importance to understanding the ecological relationships of a particular community (i.e., foraging

Table 1. Relative percent density of plant fragments in mt. goat fecal samples from Mt. Chopaka, Wash., 1977-1980.

\begin{tabular}{|c|c|c|c|c|}
\hline Plant species & Winter & Spring & Summer & Fall \\
\hline \multicolumn{5}{|l|}{ Graminoids } \\
\hline Agropyron spicatum & 12.6 & 16.3 & 18.0 & 16.5 \\
\hline Calamagrostis rubescens & 1.9 & 3.6 & 3.6 & 5.4 \\
\hline Carex spp. & 1.1 & 2.9 & 6.2 & 4.0 \\
\hline Festuca idahoensis & 7.4 & 10.6 & 4.0 & 9.4 \\
\hline Phleum alpinum & - & 2.4 & 3.5 & 1.4 \\
\hline Poa spp. & 7.4 & 7.7 & 4.7 & 8.0 \\
\hline Miscellaneous graminoids ${ }^{1}$ & 0.9 & 2.3 & 3.3 & 2.8 \\
\hline Total & 31.3 & 45.8 & 43.3 & 47.5 \\
\hline \multicolumn{5}{|l|}{ Forbs } \\
\hline Achillea lamulosa & 0.2 & 0.3 & 2.9 & 1.9 \\
\hline Arenaria spp. & - & 0.3 & 3.7 & 2.3 \\
\hline Erigeron spp. & 0.2 & 0.4 & 0.6 & 0.8 \\
\hline Eriogonum spp. & 0.1 & 0.8 & 0.5 & 0.4 \\
\hline Fern & 0.6 & 0.8 & 0.2 & 0.6 \\
\hline Fragaria spp. & 0.1 & 0.4 & 0.2 & 0.7 \\
\hline Moss champion & 0.5 & 1.3 & 0.2 & 0.6 \\
\hline Penstemon spp. & - & 0.8 & 1.7 & 1.0 \\
\hline Sedum spp. & 0.9 & 0.5 & - & 0.8 \\
\hline Verbascum thapsis & 0.3 & 0.1 & 1.5 & 0.1 \\
\hline Miscellaneous forbs ${ }^{2}$ & 0.3 & 3.1 & 8.5 & 4.2 \\
\hline Total & 3.2 & 8.8 & 20.0 & 13.4 \\
\hline \multicolumn{5}{|l|}{ Shrubs } \\
\hline Amelanchier alnifolia & 3.6 & 2.2 & 0.4 & 3.9 \\
\hline Artemisia spp. & 3.1 & 1.0 & 7.1 & 1.0 \\
\hline Berberis repens & 2.1 & 2.1 & 0.1 & 0.8 \\
\hline Ceanothus velutinus & 5.8 & 2.0 & 0.9 & 1.1 \\
\hline Ledum groenlandicum & 1.0 & 1.1 & 1.6 & 0.4 \\
\hline Philadelphus lewisii & 0.7 & 0.3 & 0.3 & 0.7 \\
\hline Physocarpos malvaceous & 2.6 & 1.7 & 1.6 & 1.5 \\
\hline Prunus spp. & 0.6 & 0.8 & 0.2 & 1.2 \\
\hline Ribes spp. & 4.8 & 6.8 & 1.4 & 3.9 \\
\hline Rosa nutkana & 0.8 & 0.7 & 1.2 & 2.4 \\
\hline Salix spp. & 1.0 & 0.2 & 1.5 & 0.8 \\
\hline Sambucus spp. & 0.9 & 0.9 & 0.5 & 0.7 \\
\hline Shepherdia canadensis & 5.0 & 4.3 & 9.3 & 6.0 \\
\hline Miscellaneous shrubs ${ }^{3}$ & 4.0 & 5.3 & 3.7 & 4.9 \\
\hline Total & 36.0 & 29.4 & 29.8 & 29.3 \\
\hline Conifers & 28.1 & 14.1 & 6.2 & 8.7 \\
\hline Lichen & 1.2 & 0.6 & 0.6 & 0.3 \\
\hline Unknown & 0.2 & 1.3 & 0.1 & 0.8 \\
\hline Total & 100.0 & 100.0 & 100.0 & 100.0 \\
\hline
\end{tabular}

Includes: Bromus spp., Koeleria cristata, Sitanion hystrix, and Stipa spp.

2Includes: Astragalus spp., Epilobium angustifolium, Heuchera spp., Hieracium spp., Lupinus spp.. Potentilla spp.. and Senecio spp.

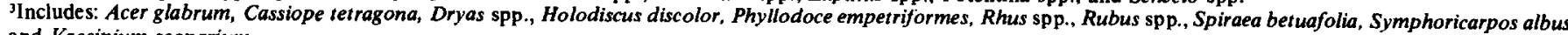
and Vaccinium scoparium. 
habits, niche structures of the various populations and the community, and energy and nutrient flow patterns within the ecosystems). Ungulate productivity can often be maximized in an area where a number of different species of ungulate are present which have differing food habits.

Land management and game and fish department personnel must consider the competition for food resources when establishing stocking rates for livestock or harvest rates for big game. There must be concern for the depletion of one ungulates forage supply by another. In this study dietary overlap between $\mathrm{mt}$. goats and mule deer as well as mt. goats and cattle would appear to be more important than that between mule deer and cattle. That, however, may not always be the case.

Mt. goats and cattle utilized little common habitat; cattle preferred the level top and base of the mountain and mt. goats occupied the steeper terrain; so possible food competition would be minimal even though $\mathrm{mt}$. goats and cattle utilized $42 \%$ and $84 \%$ graminoids, respectively. Mt. goats, however, historically occupied the level top of Chopaka Mountain prior to the introduction of the cattle. Competition may well exist between mt. goats and cattle for space, that is, the top of the mountain. The fall dietary overlap between mule deer and cattle was insignificant, $15 \%$ overall. Mt. goats and mule deer exhibited the greatest degree of dietary overlap. Mt. goats utilized graminoids $(17-70 \%)$ and shrubs (8-70\%) primarily; whereas mule deer predominantly consumed shrubs $(12-79 \%)$ and conifers $(1-74 \%)$. The period of greatest dietary overlap between the mt. goat and mule deer occurred during the spring period $(44 \%)$ and the least during the fall period (29\%). The comparative food habits data presented herein do not indicate that one species was restricting another. Forage use data would be necessary to evaluate at that facet of their competitive ecology and those data were not collected during this study.

Similar studies have documented the relatively low level of food competition between mule deer and cattle experienced in this study (15\%). Hansen and Clark (1977) determined a much lower value of $4 \%$, Hubbard and Hansen (1976) 2 to 4\%; whereas, Hansen and Reid (1975) determined forage competition to be between 12 and $38 \%$. All of these studies were conducted in Colorado. No comparative studies had ever been performed on $\mathrm{mt}$. goats prior to this study. Previous mt. goat food habits studies have documented high use of graminoids (Saunders 1955, Hibbs 1967), mosses and lichens (Harmon 1944), bunchgrasses and $\mathrm{mt}$. mahogany (Cercocarpus ledifolius) (Brandborg 1955), and shrubs (Kuck 1970). This study demonstrates a generalized preference for graminoids and shrubs, depending upon availability.

Table 2. Relative percent density of plant fragments in mule deer fecal samples from Mt. Chopaka, Wash., $1978-80$.

\begin{tabular}{|c|c|c|c|c|}
\hline Plant species & Winter & Spring & Summer & Fall \\
\hline \multicolumn{5}{|l|}{ Graminoids } \\
\hline Agropyron spicatum & - & 4.1 & 3.2 & 1.4 \\
\hline Calamagrostis rubescens & 5.3 & 2.1 & 3.2 & 2.2 \\
\hline Carex spp. & 0.1 & - & 4.8 & 4.8 \\
\hline Phleum alpinum & 5.5 & 1.3 & 0.4 & 0.8 \\
\hline Poa spp. & 2.5 & 1.5 & 2.9 & 1.4 \\
\hline Miscellaneous graminoids & 3.8 & 2.9 & 1.6 & 0.3 \\
\hline Total & 17.2 & 11.9 & 16.1 & 10.9 \\
\hline \multicolumn{5}{|l|}{ Forbs } \\
\hline Achillea lanulosa & 0.5 & 0.2 & 2.0 & 0.3 \\
\hline Astragalus spp. & 1.1 & 1.1 & 1.1 & 0.3 \\
\hline Erigeron spp. & 1.3 & 0.6 & 0.5 & 0.2 \\
\hline Fragaria spp. & 3.2 & 0.2 & 2.9 & 1.4 \\
\hline Potentilla spp. & 2.5 & 0.3 & 1.3 & 0.2 \\
\hline Miscellaneous forbs ${ }^{2}$ & 5.9 & 3.6 & 10.3 & 3.8 \\
\hline Total & 14.5 & 6.0 & 18.1 & 6.2 \\
\hline \multicolumn{5}{|l|}{ Shrubs } \\
\hline Amelanchier alnifolia & 2.3 & 5.0 & 2.8 & 1.1 \\
\hline Artemisia spp. & 1.1 & 3.7 & 0.2 & 0.8 \\
\hline Berberis repens & 10.0 & 1.9 & 0.7 & 1.7 \\
\hline Ceanothus velutinus & 6.0 & 4.5 & 3.1 & 3.0 \\
\hline Physocarpos malvaceous & 0.3 & 4.0 & 3.0 & 0.4 \\
\hline Prunus spp. & 0.2 & 0.5 & 1.1 & 0.8 \\
\hline Rhus spp. & 1.4 & 0.5 & 1.7 & 0.1 \\
\hline Ribes spp. & 9.8 & 3.2 & 2.5 & 3.4 \\
\hline Rosa nutkana & 3.1 & 1.8 & 3.9 & 1.8 \\
\hline Salix spp. & 1.3 & 2.1 & 2.6 & 6.2 \\
\hline Sambucus cerulea & 1.8 & 0.7 & 1.5 & 0.8 \\
\hline Shepherdia canadensis & 1.9 & 0.2 & 27.6 & 9.3 \\
\hline Symphoricarpos albus & 1.7 & 1.4 & 2.6 & 0.6 \\
\hline Miscellaneous shrubs ${ }^{3}$ & 6.1 & 5.0 & 8.3 & 6.8 \\
\hline Total & 47.0 & 34.5 & 61.6 & 36.8 \\
\hline Conifers & 21.1 & 47.3 & 2.4 & 46.1 \\
\hline Lichen & 0.1 & 0.3 & 1.8 & - \\
\hline Unknown & 0.1 & - & - & - \\
\hline Total & 100.0 & 100.0 & 100.0 & 100.0 \\
\hline
\end{tabular}

'Includes: Bromus spp., Dactylis glomerata, and Festuca idahoensis.

'Includes: Epilobium angustifolium, Eriogonum spp., Ferns, Heuchera spp., Lupinus spp., Penstemon spp., Senecio spp., and Verbascum thapsis.

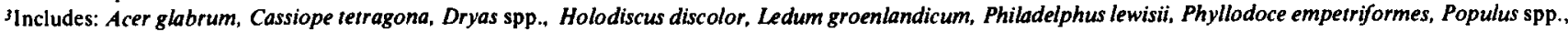

Rubus spp., and Vaccinium scoparium. 
Table 3. Relative percent density of plant fragments in cattle fecal samples from Mt. Chopaka, Wash.; 1978-80.

\begin{tabular}{|c|c|}
\hline Plant species & Fall \\
\hline $\begin{array}{l}\text { Graminoids } \\
\text { Agropyron spicatum } \\
\text { Bromus spp. } \\
\text { Calamagrostis rubescens } \\
\text { Carex spp. } \\
\text { Festuca idahoensis } \\
\text { Phleum alpinum } \\
\text { Poa spp. } \\
\text { Stipa spp. } \\
\text { Total }\end{array}$ & $\begin{array}{r}10.1 \\
1.4 \\
3.4 \\
53.1 \\
7.1 \\
0.2 \\
7.9 \\
0.6 \\
83.8\end{array}$ \\
\hline $\begin{array}{l}\text { Forbs } \\
\text { Achillea lanulosa } \\
\text { Arenaria spp. } \\
\text { Erigeron spp. } \\
\text { Eriogonum spp. } \\
\text { Heuchera cylindrica } \\
\text { Lupinus spp. } \\
\text { Miscellaneous forbs } 1 \\
\text { Total }\end{array}$ & $\begin{array}{l}3.2 \\
1.1 \\
0.2 \\
2.0 \\
0.5 \\
0.3 \\
1.3 \\
8.6\end{array}$ \\
\hline $\begin{array}{l}\text { Shrubs } \\
\text { Acer glabrum } \\
\text { Amelanchier alnifolia } \\
\text { Artemisia tridentata } \\
\text { Ceanothus velutinus } \\
\text { Philadelphus lewisii } \\
\text { Rosa nutkana } \\
\text { Salix spp. } \\
\text { Shepherdia canadensis } \\
\text { Symphoricarpos albus } \\
\text { Total } \\
\text { Conifers }\end{array}$ & $\begin{array}{l}0.5 \\
0.5 \\
0.4 \\
0.6 \\
0.5 \\
1.8 \\
0.5 \\
0.6 \\
0.9 \\
6.3 \\
1.3\end{array}$ \\
\hline Total & 100.0 \\
\hline
\end{tabular}

Includes: Cirsium arvense, Fragaria bracteala, Saxifraga tolmei, and Verbascum thapsis.

The diets of all three species of ungulates varied considerably between seasons and within a season. Cooperider et al. (1980) experienced similar variations in Rocky Mt. bighorn sheep in Colorado. These tremendous variations should caution us that one year's food habits data are insufficient to assess foraging ecology given the variation inherent to each species of ungulate.

\section{Literature Cited}

Anderson, N.A. 1940. Mountain goat study. State of Washington Dep. Game Biol. Bull. No, 2.

Anthony, R.G., and N.S. Smith. 1974. Comparison of rumen and fecal analysis to describe deer diets. J. Wildl. Manage. 38:535-540.
Brandborg, S.M. 1955. Life history and management of the mountain goat in Idaho. State of Idaho Dep. Fish and Game Wildl. Bull. 2.

Casebeer, R.L. 1948. A study of the food habits of the goat (Oreamnos americanus missoulae) in western Montana. M.S. Thesis. Montana State Univ., Missoula.

Constan, K.J. 1973. Winter foods and range use of three species of ungulates. J. Wildl. Manage. 36:1068-1076.

Cooperider, A., S. McCollough, and J. Balley. 1980. Variation in bighorn sheep food habits as measured by fecal analysis. Proc. 1980 Northern Wild Sheep and Goat Conference, Salmon, Ida. April 23-25. 1980. In press.

Dearden, B.L., R.E. Pegau, and R.M. Hansen. 1975. Precision of microhistological estimates of ruminant food habits. J. Wildl. Manage. 39:402-407.

Hansen, R.M., D.G. Peden, and R.W. Rice. 1973. Discerned fragments in feces indicates diet overlap. J. Range Manage. 26:103-105.

Hansen, R.M., and L.D. Reid. 1975. Diet overlap of deer, elk, and cattle in southern Colorado. J. Range Manage. 28:43-47.

Hansen, R.M., and R.C. Clark. 1977. Foods of elk and other ungulates at low elevations in northwestern Colorado. J. Wildl. Manage. 41:76-80.

Hansen, R.M., R.C. Clark, and W. Lawhom. 1977. Foods of wild horses, deer, and cattle in the Douglas Mountain area, Colorado. J. Range Manage. 30:116-118.

Harmon, W. 1944. Notes on mountain goats in the Black Hills. J. Mammal. 25:149-151.

Hibbs, L.O. 1967. Food habits of the mountain goat in Colorado. J. Mammal. 48:242-248.

Hubbard, R.E., and R.M. Hansen. 1976. Diets of wild horses, cattle, and mule deer in the Piceance Basin, Colorado. J. Range Manage. 29:389392.

Julander, 0. 1955. Deer and cattle range relations in Utah. Forest Sci. 1:130-139.

Kuck, L. 1970. Rocky Mountain goat ecology. State of Idaho Fish and Game Dep. P-R Project Rep. W-144-R-OZ.

Mackle, R.J. 1970. Range ecology and relations of mule deer, elk, and cattle in the Missouri River Breaks, Montana. Wildlife Monogr. No. 20.

McKean, W.T., and R.W. Bartmann. 1971. Deer-livest ock relations of a pinyon-juniper range in northwestern Colorado. Colorado Game, Fish, and Parks Rep. W-101-R.

Oosting, H.S. 1956. The study of plant communities. W.H. Freeman and Co., San Francisco.

Saunders, J.K. 1955. Food habits and range use of the Rocky Mountain goat in the Crazy Mountains, Montana. J. Wildl. Manage. 19:429-437.

Schwan, H.E. 1945. Big game and livest ock on the western range. Trans. N Amer. Wildl. Conf. 10:219-224.

Sparks, D.R., and J.C. Malechek. 1968. Estimating percentage dry weights in diets using a microscope technique. J. Range Manage. 21:264-265.

Storr, G.M. 1961. Microscopic analysis of feces, a technique for ascertaining the diet of herbivorous mammals. Australian J. Biol. Sci. 14: [ 57-164.

Todd, J.W., and R.M. Hansen. 1973. Plant fragments in the feces of bighorns as indicators of food habits. J. Wildl. Manage. 37:363-366.

Ward, A.L. 1970. Stomach content and fecal analysis: methods of forage identifiction. In: Range and Wildlife Habitat Evaluation: A Research Symposium. USDA Misc. Pub. 1147.

Williams, O.B. 1969. An improved technique for identification of plant fragments in herbivore feces. J. Range Manage. 22:51-52.

\section{3 BRANDAIDS Needed?}

Copies of BRANDAIDS, the booklet developed by the Society for Range Management to help ranchers weather the difficult financial climate, are available from the Society headquarters, 2760 West 5th Avenue, Denver, CO 80204. A single copy per individual for a single instance is available free of charge. Two to 100 copies may be purchased @75c each, postpaid; more than 100 are $50 \mathrm{c}$ each. Please allow 2 weeks delivery after receipt of your order. 